\title{
NOTES
}

\section{A HOODED CRANE (GRUS MONACHA) AT DELTA JUNCTION, A FIRST FOR ALASKA}

JACK J. WITHROW, University of Alaska Museum, Fairbanks, Alaska 99775; jjwithrow@alaska.edu

MICHAEL LENZE, Goose Shack Guide Service, 735 Orion Drive, North Pole, Alaska 99705

On 29 September 2020, while crane hunting near Delta Junction, Alaska $\left(64^{\circ} 02^{\prime}\right.$ $\mathrm{N}, 145^{\circ} 44^{\prime} \mathrm{W}$ ), Lenze took a Hooded Crane (Grus monacha) when it landed among decoys with a flock of $70+$ Sandhill Cranes (Antigone canadensis). The bird had been in the vicinity for several days, but its exact arrival date is unknown. The specimen (University of Alaska Museum 45000) was a male weighing 3300 g, with light fat; it appeared to be in good health. We inferred that the bird was in its second year ( 15 months old) from its adult-like head and neck plumage, unlike that of first fall juveniles, which do not have a black crown/forehead patch (Figure 1). The relatively worn, brownish remiges that are uniformly shorter than one replaced secondary on the right wing (Figure 2) represent juvenal feathers (i.e., first generation). The replaced secondary 5 and other feathers appeared too new to have gone through a year's wear and had likely been replaced as part of the second prebasic molt before the bird started its southward migration. The tail had two retained juvenal feathers (faded and shorter than the rest) on the right side, and there were at least two generations of feathers in the wing coverts (Figure 2). The details of molt in cranes, the Hooded Crane being no exception, are not well understood (see Howell 2010,

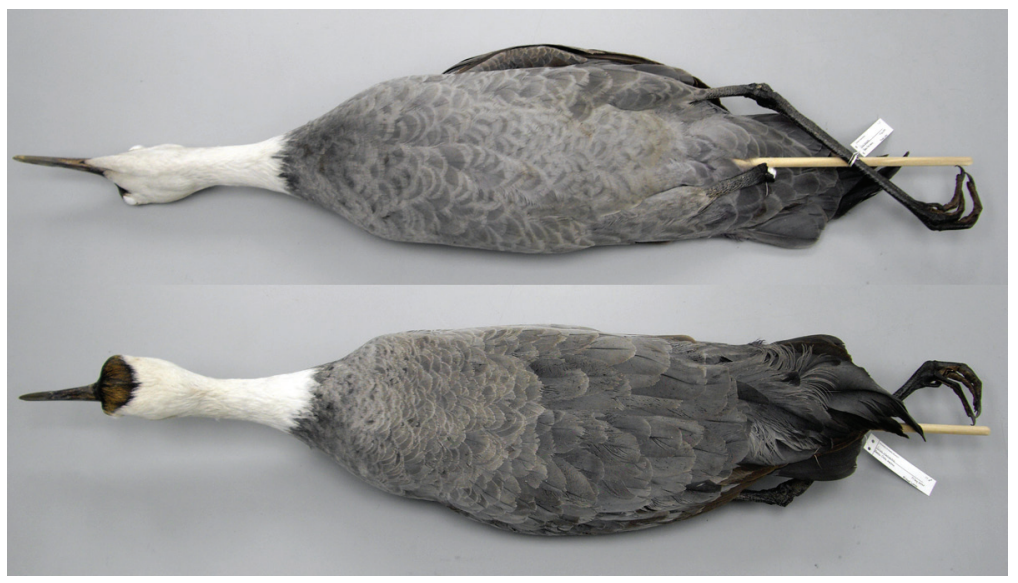

FIgURE 1. Dorsal and ventral views of the Hooded Crane specimen from Delta Junction, Alaska, 29 September 2020 (UAM 45000). The right leg remained with the partial skeleton. In addition to the skin and skeleton, a separate spread wing (Figure 2), duplicate tissue samples, a section of the lower gastrointestinal tract, and external parasites from the bird were preserved and archived. 


\section{NOTES}

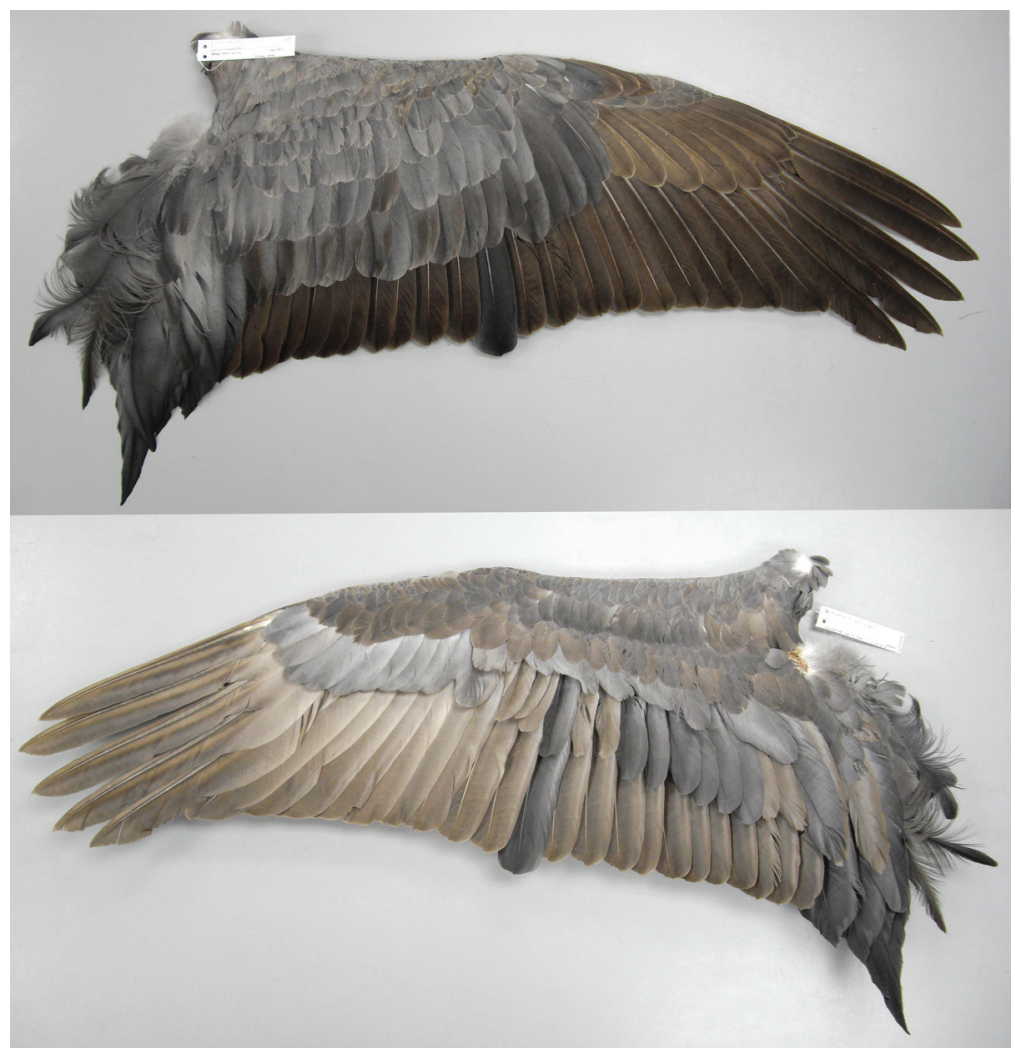

FIGURE 2. Upper (top) and under (bottom) wing views of the right wing of the Hooded Crane (UAM 45000) showing a complex mix of retained juvenal (browner) and replaced second-generation feathers (grayer). All of the remiges except for secondary five (s5) and the innermost four (tertials) are juvenal, as implied by their uniformly shorter length in comparison to s5 and overall faded brown appearance. The replacement of the tertials and s5 represents a common pattern for second basic plumage among diastataxic species with incomplete molt of the remiges, such as cranes (Pyle 2008). On the upper side of the wing the greater primary coverts are juvenal except for the innermost, which has been replaced. On both the upper and undersides of the wing the secondary coverts comprise a mixture of two or three feather generations including juvenal, second basic, and, possibly, some formative coverts. Molt patterns on the left wing were largely similar except s5 had not been replaced (the tertials had). We interpret this pattern to represent a bird in its second fall, i.e., about 15 months old (see text).

\section{Photos by Jack J. Withrow}

Rohwer and Rohwer 2018), but at least in other species of smaller cranes, a bird in its third fall is likely to have replaced more wing feathers (see Nesbitt and Schwikert 2005, Pyle 2008, Masatomi 2020).

The Hooded Crane was accepted unanimously by the Alaska Checklist Committee as a wild bird. The occurrence in fall, of a second-year bird, migrating with 
Sandhill Cranes in Alaska, is compelling evidence of unassisted wild origin. Hooded Cranes are not kept in captivity in Alaska (S. Jensen, Alaska Zoo, in litt., 2021), and only 30 are registered with the Association of Zoos and Aquariums (AZA) for North America. None of these had been lost recently (J. Azua, Denver Zoo, AZA, in litt., 2021). How and where this bird may have taken up with Sandhill Cranes bound for North America is unknowable, but immature and/or nonbreeding Hooded Cranes are known to wander widely in Mongolia, northeast China, and the Amur River region of eastern Russia during the summer months (Johnsgard 1983, Mi et al. 2018). The Hooded Crane's breeding range is not well understood (Degtyarev 2020), although it is centered on the upper Lena and Amur river basins, including parts of extreme northeast China (Rank 1993). It is not known to be closer than $\sim 1000 \mathrm{~km}$ south and west of the Sandhill Crane's breeding range in Russia, which extends west along the coast of the Arctic Ocean to the deltas of the Yana, Indigirka, and Kolyma rivers (Krapu and Brandt 2005, Watanabe 2006 and citations therein). Perhaps more likely than spring overshooting or summer wandering by a second-year bird, this crane may have taken up with the small (but increasing) numbers of Sandhill Cranes that winter with Hooded Cranes in Japan (Gao et al. 2019) and subsequently migrated north and then south with Sandhill Cranes. The most recent estimate of the Hooded Crane's population, from winter 2014-2015, was of 15,000 individuals, trending upward from a decade before (BirdLife International 2021; datazone.birdlife.org/species/factsheet/hooded-crane-grus-monacha/text, accessed 15 Jan 2021).

Most Hooded Cranes winter in southern Japan; numbers wintering in South Korea and eastern China are much smaller (del Hoyo and Collar 2014). To our knowledge, extralimital occurrences of the Hooded Crane are scarce, but interestingly the two other accidental occurrences we were able to find were also in 2020. In February a flock of seven was observed in the Philippines (G. Laude, www.ebird. org, Macaulay Library 211642441+), and in April a lone bird was shot by a hunter in Pakistan (Karam and Shaikh 2020). The Hooded Crane is apparently casual in Taiwan (Ding et al. 2017) and on the hypothetical list in India (Rasmussen and Anderton 2005; see also Dement'ev and Gladkov 1951). Patterns, if any, of extralimital occurrence north of breeding areas are unknown to us.

The Tanana River valley is a major migratory corridor for Sandhill Cranes breeding in western Alaska and Siberia (Kessel 1984, Krapu et al. 2011), and most or all of the cranes breeding in those areas pass through the Tanana Valley in spring and fall. The segment of the Sandhill Crane population that nests in western Alaska and Siberia appears to migrate through the Tanana River valley somewhat later than do birds from interior Alaska (Krapu et al. 2011). Most cranes have departed the Tanana Valley by October, and the Hooded Crane was thus at the tail end of this movement.

The area around Delta Junction is one of few areas in Alaska that has significant agriculture (predominantly barley, hay, or pastures; see Thomas and Lewis 1981) and is used as a stop-over and feeding site for large numbers of migratory waterfowl and cranes in both spring and fall. Alaska's two records of the Common Crane (Grus grus), another Asian species that has occurred in North America, also come from this area. One Common Crane at Fairbanks ( 150 km northwest of Delta Junction) 24 April-10 May 1958 (Kessel and Kelly 1958) arrived a week before the Sandhill Cranes and "showed no particular affinity toward them" once they did arrive. The second, at Delta Junction 15-20 September 1998 (Tobish 1999), was also associated with Sandhill Cranes. The only other Asian species of crane that has been recorded in Alaska was a Demoiselle Crane (Grus virgo) found in southeast Alaska at Gustavus 13-18 May 2002. Circumstantial evidence suggests it was the same Demoiselle Crane that had wintered in California and was subsequently seen in British Columbia just before it arrived in Alaska (see Cole and McCaskie 2004). The Alaska Checklist Committee unanimously decided to treat that bird as of questionable origin (see also Chesser et al. 2015). 


\section{NOTES}

The only other reports of the Hooded Crane in North American are of one (or more?) birds seen in Idaho, Nebraska, Tennessee, and Indiana from April 2010 to February 2012. Chesser et al. (2015:761) characterized the unassisted wild origins of that (those?) Hooded Crane(s) as "best considered unresolved" (see also Pranty et al. 2014, 2015, Pranty 2015, cf. Brogie 2013, Kendall et al. 2015). The Hooded Crane at Delta Junction would no doubt have continued south with Sandhill Cranes, tempering the issues of provenance that plagued the previous history of this species in North America.

The Alaska Department of Fish and Game forwarded the frozen specimen to UAM. The Alaska Checklist Committee provided useful discussions of natural occurrence and other extralimital records of the Hooded Crane. Peter Pyle and Philip Unitt offered constructive reviews.

\section{LITERATURE CITED}

Brogie, M. A. 2013. $2012\left(24^{\text {th }}\right)$ report of the Nebraska Ornithologists' Union Records Committee. Nebr. Bird Rev. 8:120-130.

Chesser, R. T., Banks, R. C., Burns, K. J., Cicero, C., Dunn, J. L., Kratter, A. W., Lovette, I. J., Navarro-Sigüenza, A. G., Rasmussen, P. C., Remsen, J. V., Jr., Rising, J. E., Stotz, D. F., and Winker, K. 2015. Fifty-sixth supplement to the American Ornithologists' Union Check-list of North American Birds. Auk 132:748-764; doi.org/10.1642/AUK-15-73.1.

Cole, L. W., and McCaskie, G. 2004. Report of the California Bird Records Committee: 2002 records. W. Birds 35:2-31.

Degtyarev, V. G. 2020. Identification of the breeding range of the Hooded Crane. Ornithol. Sci. 19:15-27; doi.org/10.2326/osj.19.15.

Del Hoyo, J., and Collar, N. J. 2014. HBW and BirdLife International Illustrated Checklist of the Birds of the World, Vol. 1: Non-passerines. Lynx Edicions, Barcelona.

Dement'ev, G. P., and Gladkov, N. A. 1951. Birds of the Soviet Union, vol. II. Israel Program for Scientific Translations, Jerusalem [English translation, 1968].

Ding, T.-S., Juan, C.-S., Lin, R.-S., Pan, C.-Y. , Tsai, Y.-J., Wu, J., and Yang, Y.-H. 2017. The 2017 C.W.B.F. Checklist of the Birds of Taiwan. Chinese Wild Bird Federation, Taipei, Taiwan.

Gao, L., Mi, C., and Guo, Y. 2019. Expansion of Sandhill Cranes (Grus canadensis) in east Asia during the non-breeding period. PeerJ 7:e7545; doi.org/10.7717/ peerj.7545.

Howell, S. N. G. 2010. Molt in North American Birds. Houghton Mifflin Harcourt, New York.

Johnsgard, P. A. 1983. Cranes of the World. Indiana Univ. Press, Bloomington.

Karam, A., and Shaikh, Z. A. 2020. First confirmed record of Hooded Crane Grus monacha for south Asia from a tragically hunted individual in Khyber Pakhtunkhwa, Pakistan. Indian Birds 16:50-52.

Kendall, J., Brogie, M. A., and Calhoon, K. 2015. The Hooded Crane in the ABA area. Birding 47:26-31.

Kessel, B. 1984. Migration of Sandhill Cranes, Grus canadensis, in east-central Alaska, with routes through Alaska and western Canada. Can. Field-Nat. 98:279-292.

Kessel, B., and Kelly, R. W. 1958. First North American sighting and photographic record of Common Crane, Grus grus. Auk 75:465; doi.org/10.2307/4082103.

Krapu, G. L., and Brandt, D. A. 2005. Migration routes, staging areas, and wintering grounds of Sandhill Cranes that breed in Siberia. Proc. N. Am. Crane Workshop 9:252.

Krapu, G. L., Brandt, D. A., Jones, K. L., and Johnson, D. H. 2011. Geographic dis- 


\section{NOTES}

tribution of the mid-continent population of Sandhill Cranes and related management applications. Wildlife Monogr. 175:1-38; doi.org/10.1002/wmon.1.

Masatomi, Y. 2020. Age of first primary moult in the Red-crowned Crane Grus japonensis. Ornithol. Sci. 19:223-226; doi.org/10.2326/osj.19.223.

Mi, C., Møller, A. P., and Guo, Y. 2018. Annual spatio-temporal migration patterns of Hooded Cranes wintering in Izumi based on satellite tracking and their implications for conservation. Avian Res. 9:23; doi.org/10.1186/s40657-018-0114-9.

Nesbitt, S. A., and Schwikert, S. T. 2005. Wing-molt patterns-a key to aging Sandhill Cranes. Wildlife Soc. Bull. 33:326-331; doi.org/10.2193/00917648(2005)33[326:FTFWPK]2.0.CO;2.

Pranty, B. 2015. The ABA Checklist Committee chair responds to the Hooded Crane commentary. Birding 47:34-40.

Pranty, B., Barry, J., Dunn, J. L., Garrett, K. L., Gibson, D. D., Lockwood, M. W., Pittaway, R., and Sibley, D. A. 2014. $25^{\text {th }}$ report of the ABA Checklist Committee 2013-2014. Birding 46:26-36.

Pranty, B., Barry, J., Dunn, J. L., Garrett, K. L., Gibson, D. D., Lang, A., Lockwood, M. W., Pittaway, R., Pyle, P., and Sibley, D. A. $2015.26^{\text {th }}$ report of the ABA Checklist Committee 2015. Birding 47:26-33; doi.org/10.1007/s15016-015-0680-6.

Pyle, P. 2008. Identification Guide to North American Birds, part 2. Slate Creek Press, Point Reyes Station, CA.

Rank, M. 1993. Hooded Crane breeds in China. Oriental Bird Club Bull. 18:18.

Rasmussen, P. C., and Anderton, J. C. 2005. Birds of South Asia: The Ripley Guide, vol. 2. Smithsonian Inst. and Lynx Edicions, Washington, D. C., and Barcelona.

Rohwer, S., and Rohwer, V. G. 2018. Primary molt in Gruiforms and simpler molt summary tables. PeerJ 6:e5499; doi.org/10.7717/peerj.5499.

Thomas, W. C., and Lewis, C. E. 1981. Alaska's Delta Agricultural Project: A review and analysis. Agric. Admin. 8:357-374; doi.org/10.1016/0309586X(81)90014-5.

Tobish, T. G. Jr. 1999. Alaska region (fall 1998). N. Am. Birds 53:89-91.

Watanabe, T. 2006. Comparative breeding ecology of Lesser Sandhill Cranes (Grus canadensis canadensis) and Siberian Cranes (G. leucogeranus) in eastern Siberia. Ph. D. dissertation, Texas A\&M Univ., College Station.

Accepted 23 February 2021 